\title{
Pengaruh Fasilitas Kerja Terhadap Motivasi Kerja Pegawai di Kantor Pelayanan Pajak
}

\author{
${ }^{1}$ Marnala Panjaitan, ${ }^{2}$ Nurbasariah, ${ }^{3}$ Patigor, ${ }^{4}$ Indri Yani Sukma \\ ${ }^{1-4}$ Program Magister Manajemen, Fakultas Ekonomi, Universitas Islam Sumatera Utara \\ Article history \\ Received: 18 Nov 2020 \\ Revised: 13 Dec 2020 \\ Accepted: 30 Dec 2020 \\ *Corresponding Author: \\ Marnala Panjaitan, Program \\ Studi Magister Manajemen, \\ Fakultas Ekonomi, \\ Universitas Islam Sumatera \\ Abstrak: Penelitian ini mengungkapkan pengaruh fasilitas kerja terhadap motivasi \\ kerja pegawai di Kantor Pelayanan Pajak Pratama Lubuk Pakam. Penelitian ini \\ menggunakan metode penelitian kuantitatif dengan pendekatan deskriptif. Populasi \\ penelitian ini sebanyak 109 orang dan sampel sebanyak 52 orang. Hasil penelitian ini \\ memberikan kesimpulan bahwa secara statistik fasilitas kerja terbukti berpengaruh \\ terhadap motivasi kerja pegawai di Kantor Pelayanan Pajak Pratama Lubuk Pakam. \\ Nilai $p$-value (pada kolom Sig.) $0,003<0,05$.
}

Utara

Email:

marnalapanjaitan@gmail.co $\underline{\mathrm{m}}$

Kata Kunci : Pengaruh, Fasilitas Kerja, Motivasi Kerja, Pelayanan Pajak

\section{PENDAHULUAN}

Sumber Daya Manusia (SDM) merupakan unsur terpenting bagi organisasi. Tanpa adanya unsur manusia sebagai pegawai, maka tujuan organisasi tidak akan tercapai seperti apa yang diharapkan. Berhasilnya suatu proses pencapaian tujuan organisasi yang telah ditetapkan sangat tergantung pada unsur manusia yang memimpin dan melaksanakan tugastugas serta kegiatan yang dilakukan untuk mencapai tujuan. Dalam konteks Pemerintahan, maka pegawai merupakan alat penggerak segala pekerjaan atau kegiatan-kegiatan penyelenggaraan Negara, pemerintahan dan pembangunan.

Kondisi pelaksanaan tugas Kantor Pelayanan Pajak Pratama Lubuk Pakam pada dasarnya mengandung prinsip yang jelas dan pasti, yaitu bahwa seluruh penyelenggaraan manajemen kepegawaian daerah dilaksanakan berdasarkan norma, standar dan prosedur yang ditetapkan Pemerintah di dalam Undang-Undang dan Peraturan Pemerintah serta ketentuanketentuan pelaksanaannya. Akan tetapi ada beberapa permasalahan yang ditemui adalah bahwa integritas Pegawai Negeri Sipil (PNS) atau pejabat terhadap berbagai bidang layanan perpajakan oleh Kantor Pajak masih ada yang belum memenuhi ketentuan standar dan prosedur yang ditetapkan Kantor Pajak.

Terry (2003) mengemukakan bahwa fasilitas kerja merupakan kelengkapan kerja yang harus dimiliki oleh organisasi. Aktivitas pegawai di suatu organisasi memerlukan fasilitas yang mendukung pekerjaannya agar aktivitas organisasi berjalan sesuai tujuan organisasi. Seorang pegawai harus dapat mengoperasikan atau memanfaatkan fasilitas yang ada. 
Menurut Siagian (2003), fasilitas kerja merupakan suatu bentuk pelayanan kantor pajak terhadap pegawai agar menunjang kinerja dalam memenuhi kebutuhan pegawai, sehingga dapat meningkatkan kinerja pegawai”. Fasilitas kerja tersebut sebagai alat atau sarana dan prasarana untuk membantu pegawai agar lebih mudah menyelesaikan pekerjaannya dan pegawai akan bekerja lebih produktif.

Susilo (2002) membagi fasilitas kerja menjadi dua macam, yaitu: sarana dan prasarana. Lebih lanjut Susilo (2002) mengungkapkan definisi dari sarana adalah segala sesuatu yang berkaitan secara langsung dengan pegawai dan mendukung kelancaran serta keberhasilan proses kerja yang meliputi ruangan kerja, penerangan, perlengkapan lainnya seperti komputer, lemari, meja, kursi dan lain sebagainya. Sedangkan Prasarana merupakan segala sesuatu yang tidak secara langsung berkaitan dengan pegawai, namun dapat mendukung kelancaran dan keberhasilan proses kerja pegawai yang meliputi jalan, kamar kecil dan lain sebagainya. Prasarana Dinas adalah segala sesuatu yang dipergunakan pegawai dalam pelaksanaan pekerjaan.

Faktor motivasi yang akan mempengaruhi kinerja pegawai yang dimiliki seseorang adalah merupakan potensi, dimana seseorang belum tentu bersedia untuk mengerahkan segenap potensi yang dimilikinya untuk mencapai hasil yang optimal, sehingga masih diperlukan adanya pendorong agar seorang pegawai Kantor Pelayanan Pajak Pratama Lubuk Pakam mau menggunakan seluruh potensinya. Daya dorong tersebut sering disebut motivasi. Melihat kenyataan tersebut, sudah saatnya pimpinan dapat lebih banyak memberikan kesempatan kepada pegawai mengembangkan sumber daya manusia agar lebih berprestasi dalam melaksanakan tugas pelayanan terhadap masyarakat.

Menurut Gibson (2006) motivasi dilihat atas dasar pembentukannya terbagi atas dua jenis, yaitu motivasi bawaan dan motivasi yang dipelajari. Motivasi bawaan merupakan motivasi yang dibawa sejak lahir, motivasi ini juga disebut sebagai motivasi primer yang terjadi dengan sendirinya tanpa harus dipelajari. Motivasi yang dipelajari adalah motivasi yang terjadi karena adanya komunikasi dan isyarat sosial serta secara sengaja dipelajari oleh manusia. Jika dilihat atas dasar fungsinya motivasi terbagi atas motivasi dan motivasi ekstrinsik (Handoko, 2001).

\section{METODE PENELITIAN}

\section{Populasi dan Sampel}

Menurut Sugiyono (2007:55), populasi adalah wilayah generalisasi yang terdiri atas obyek yang mempunyai kuantitas dan karakteristik tertentu yang ditetapkan oleh peneliti 
untuk dipelajari dan kemudian ditarik kesimpulannya. Jadi populasi bukan hanya orang, tetapi juga benda-benda alam yang lain. Maka yang menjadi populasi dalam penelitian ini adalah seluruh pegawai di Kantor Pelayanan Pajak Pratama Lubuk Pakam yang berjumlah 109 orang. Pengukuran sampel menjadi langkah untuk menentukan besarnya sampel yang diambil dalam melaksanakan penelitian suatu objek. Besar sample pada penelitian ini ditentukan dengan teori Solvin, sehingga diperoleh sample sebesar 52 orang.

\section{Teknik Pengumpulan Data}

Pengumpulan data penelitian dilakukan dengan cara pengisian kuisioner dan wawancara untuk memperoleh data primer, sesuai dengan tujuan penelitian. Peneliti menemui responden secara langsung, tentunya sesuai dengan peraturan dan tidak mengganggu kelangsungan proses kerja di Kantor Pelayanan Pajak Pratama Lubuk Pakam. Teknik yang digunakan dalam pengumpulan data menggunakan kuesioner (angket), studi pustaka, studi dokumentasi, defenisi operasional variabel, dan pengujian instrumen.

\section{Teknik Analisis Data}

Teknik analisis data yang digunakan dalam penelitian ini terdiri dari analisis deskriptif, uji asumsi klasik, koefisien determinan, regresi berganda dan hierarchical regression (regresi bertingkat). Teknik analisis data lain yang digunakan adalah uji kelayakan model (uji F) dan uji hipotesis (uji t).

\section{PEMBAHASAN}

Dalam penelitian ini peneliti menyebarkan kuesioner pada 52 orang pegawai di Kantor Pelayanan Pajak Pratama Lubuk Pakam. Dari jumlah yang dibagikan tersebut yang kembali berjumlah 52 eksemplar. Seluruh kuesioner yang kembali, dijadikan sampel dalam penelitian ini:

Tabel 1. Hasil Statistik Deskriptif

\begin{tabular}{|c|c|c|c|c|c|c|c|}
\hline \multirow{2}{*}{ Variabel } & \multirow{2}{*}{ Instrumen } & \multicolumn{6}{|c|}{ Frekwensi (Persentase) } \\
\hline & & 5 & 4 & 3 & 2 & 1 & Total \\
\hline \multirow{7}{*}{$\begin{array}{l}\text { Fasilitas Kerja } \\
\text { (X1) }\end{array}$} & 1. FK1 & 21,2 & 55,8 & 23,1 & 0 & 0 & 100 \\
\hline & 2. FK2 & 7,7 & 55,8 & 36,5 & 0 & 0 & 100 \\
\hline & 3. FK3 & 17,3 & 59,6 & 23,1 & 0 & 0 & 100 \\
\hline & 4. FK4 & 34,6 & 59,6 & 5,8 & 0 & 0 & 100 \\
\hline & 5. FK5 & 40,4 & 53,8 & 5,8 & 0 & 0 & 100 \\
\hline & 6. FK6 & 30,8 & 53,8 & 15,4 & 0 & 0 & 100 \\
\hline & 7. FK7 & 48,1 & 50,0 & 1,9 & 0 & 0 & 100 \\
\hline
\end{tabular}




\begin{tabular}{|c|c|c|c|c|c|c|c|}
\hline & 8. $\mathrm{FK} 8$ & 59,6 & 38,5 & 1,9 & 0 & 0 & 100 \\
\hline & 9. FK9 & 34,6 & 61,5 & 3,8 & 0 & 0 & 100 \\
\hline & 10. FK10 & 21,2 & 57,7 & 17,3 & 3,8 & 0 & 100 \\
\hline \multirow{10}{*}{$\begin{array}{l}\text { Motivasi Kerja } \\
\text { (X3) }\end{array}$} & 1. $\mathrm{MK} 1$ & 15,4 & 71,2 & 13,5 & 0 & 0 & 100 \\
\hline & 2. $\mathrm{MK} 2$ & 15,4 & 78,8 & 5,8 & 0 & 0 & 100 \\
\hline & 3. MK3 & 15,4 & 69,2 & 15,4 & 0 & 0 & 100 \\
\hline & 4. MK4 & 17,3 & 76,9 & 5,8 & 0 & 0 & 100 \\
\hline & 5. MK5 & 34,6 & 57,7 & 7,7 & 0 & 0 & 100 \\
\hline & 6. MK6 & 34,6 & 63,5 & 1,9 & 0 & 0 & 100 \\
\hline & 7. MK7 & 17,3 & 76,9 & 5,8 & 0 & 0 & 100 \\
\hline & 8. MK8 & 25,0 & 38,5 & 36,5 & 0 & 0 & 100 \\
\hline & 9. МK9 & 34,6 & 51,9 & 13,5 & 0 & 0 & 100 \\
\hline & 10. MK10 & 26,9 & 61,5 & 11,5 & 0 & 0 & 100 \\
\hline
\end{tabular}

Sumber: Hasil Penelitian 2020

Dari tabel di atas dapat disimpulkan, sebagai berikut:

1. Jawaban responden mengenai penerangan di ruang kerja sudah baik sebanyak $21,2 \%$ menjawab sangat setuju, setuju sebanyak 55,8\% dan kurang setuju sebanyak $23,1 \%$.

2. Jawaban responden mengenai setiap pegawai mempunyai meja dan kursi masingmasing sebanyak 7,7\% menjawab sangat setuju, setuju sebanyak 55,8\% dan kurang setuju sebanyak $36,5 \%$.

3. Jawaban responden mengenai setiap pegawai mempunyai computer sebanyak $17,3 \%$ menjawab sangat setuju, setuju sebanyak 59,6\% dan kurang setuju sebanyak $23,1 \%$.

4. Jawaban responden mengenai lemari untuk menyimpan dokumen telah tersedia sebanyak 34,6\% menjawab sangat setuju, setuju sebanyak 59,6\% dan kurang setuju sebanyak $5,8 \%$.

5. Jawaban responden mengenai sirkulasi udara diruang kerja sudah baik sebanyak $40,4 \%$ menjawab sangat setuju, setuju sebanyak 53,8\% dan kurang setuju sebanyak $5,8 \%$.

6. Jawaban responden mengenai kendaraan dinas telah tersedia untuk pelayanan ke lapangan sebanyak 30,8\% menjawab sangat setuju, setuju sebanyak 53,8\% dan kurang setuju sebanyak $15,4 \%$. 
7. Jawaban responden mengenai fasilitas $\mathrm{AC}$ atau Kipas angin telah tersedia dan dalam keadaan baik sebanyak 48,1\% menjawab sangat setuju, setuju sebanyak $50,0 \%$ dan kurang setuju sebanyak $1,9 \%$.

8. Jawaban responden mengenai lapangan parkir telah tersedia dan mampu menampung banyak kendaraan sebanyak 59,6\% menjawab sangat setuju, setuju sebanyak 38,5\% dan kurang setuju sebanyak 1,9\%.

9. Jawaban responden mengenai jaringan internet telah tersedia dengan baik sebanyak 34,6\% menjawab sangat setuju, setuju sebanyak $61,5 \%$ dan kurang setuju sebanyak $3,8 \%$.

10. Jawaban responden mengenai fasilitas toilet telah tersedia dengan baik sebanyak $21,2 \%$ menjawab sangat setuju, setuju sebanyak $57,7 \%$, kurang setuju sebanyak $17,3 \%$ dan tidak setuju sebanyak $3,8 \%$.

11. Jawaban responden mengenai berkerja dilingkungan yang harmonis sebanyak $15,4 \%$ menjawab sangat setuju, setuju sebanyak $71,2 \%$ dan kurang setuju sebanyak $13,5 \%$.

12. Jawaban responden mengenai pencapaian prestasi kerja menggerakkan saya untuk bekerja lebih baik sebanyak 15,4\% menjawab sangat setuju, setuju sebanyak $78,8 \%$ dan kurang setuju sebanyak $5,8 \%$.

13. Jawaban responden mengenai merasa dihargai apabila mendapatkan pengakuan terhadap pekerjaan yang saya lakukan sebanyak 15,4\% menjawab sangat setuju, setuju sebanyak $69,2 \%$ dan kurang setuju sebanyak $15,4 \%$.

14. Jawaban responden mengenai atasan memberikan kesempatan untuk mengembangkan potensi diri melalui pendidikan dan pelatihan sebanyak 17,3\% menjawab sangat setuju, setuju sebanyak $76,9 \%$ dan kurang setuju sebanyak $5,8 \%$.

15. Jawaban responden mengenai lebih nyaman bekerja di KPP Pratama Lubuk Pakam ini sebanyak 34,6\% menjawab sangat setuju, setuju sebanyak 57,7\% dan kurang setuju sebanyak $7,7 \%$.

16. Jawaban responden mengenai gaji yang saya terima memberikan dorongan untuk bekerja lebih baik sebanyak 34,6\% menjawab sangat setuju, setuju sebanyak $63,5 \%$ dan kurang setuju sebanyak $1,9 \%$.

17. Jawaban responden mengenai bekerja untuk menghidupi kebutuhan keluarga sebanyak $17,3 \%$ menjawab sangat setuju, setuju sebanyak $76,9 \%$ dan kurang setuju sebanyak $5,8 \%$. 
18. Jawaban responden mengenai membutuhkan keamanan dan keselamatan kerja dalam bekerja sebanyak 25,0\% menjawab sangat setuju, setuju sebanyak 38,5\% dan kurang setuju sebanyak $38,5 \%$.

19. Jawaban responden mengenai kondisi kerja yang nyaman, aman, dan tenang serta didukung oleh peralatan yang memadai sebanyak 34,6\% menjawab sangat setuju, setuju sebanyak 51,9\% dan kurang setuju sebanyak 13,5\%.

20. Jawaban responden mengenai dapat memberikan kenyamanan kerja, bertanggung jawab atas semua pekerjaan yang saya lakukan sebanyak 26,9\% menjawab sangat setuju, setuju sebanyak $61,5 \%$ dan kurang setuju sebanyak $11,5 \%$.

\section{Uji Kualitas Data}

\section{Uji Validitas}

Pengujian validitas instrumen dapat dilihat pada kolom Corrected Item-Total Correlation. Jika angka korelasi yang diperoleh lebih besar dari pada angka kritik (r-hitung > r-tabel) maka instrumen tersebut dikatakan valid. berdasarkan uji validitas dapat disimpulkan bahwa seluruh item pertanyaan untuk mengukur masing-masing variabel penelitian dinyatakan valid. Hasil uji validitas variabel adalah sebagai berikut:

Tabel 2. Hasil Uji Validitas

\begin{tabular}{|c|c|c|c|c|}
\hline Variabel & Instrumen & r-hitung & r-tabel & Keterangan \\
\hline \multirow{10}{*}{$\begin{array}{l}\text { Fasilitas Kerja } \\
\text { (X1) }\end{array}$} & 1) $\mathrm{FK} 1$ & 0.452 & 0.273 & Valid \\
\hline & 2) $\mathrm{FK} 2$ & 0.405 & 0.273 & Valid \\
\hline & 3) $\mathrm{FK} 3$ & 0.562 & 0.273 & Valid \\
\hline & 4) $\mathrm{FK} 4$ & 0.545 & 0.273 & Valid \\
\hline & 5) $\mathrm{FK} 5$ & 0.515 & 0.273 & Valid \\
\hline & 6) FK6 & 0.408 & 0.273 & Valid \\
\hline & 7) $\mathrm{FK} 7$ & 0.459 & 0.273 & Valid \\
\hline & FK8 & 0.459 & 0.273 & Valid \\
\hline & 9) $\mathrm{FK} 9$ & 0.455 & 0.273 & Valid \\
\hline & 10) FK10 & 0.569 & 0.273 & Valid \\
\hline \multirow{6}{*}{$\begin{array}{l}\text { Motivasi Kerja } \\
\text { (X3) }\end{array}$} & 1) $\mathrm{MK} 1$ & 0.321 & 0.273 & Valid \\
\hline & MK2 & 0.345 & 0.273 & Valid \\
\hline & MK3 & 0.302 & 0.273 & Valid \\
\hline & MK4 & 0.437 & 0.273 & Valid \\
\hline & MK5 & 0.694 & 0.273 & Valid \\
\hline & MK6 & 0.643 & 0.273 & Valid \\
\hline
\end{tabular}




\begin{tabular}{lllll}
\hline 7) & MK7 & 0.716 & 0.273 & Valid \\
8) & MK8 & 0.657 & 0.273 & Valid \\
9) & MK9 & 0.722 & 0.273 & Valid \\
10) & MK10 & 0.572 & 0.273 & Valid \\
\hline
\end{tabular}

Sumber : Hasil Penelitian 2020

\section{Uji Reliabilitas}

Uji reliabilitas dilakukan untuk mengetahui apakah alat pengukur yang digunakan dapat diandalkan dan tetap konsisten jika pengukuran tersebut diulang. Suatu kuesioner dikatakan reliabel jika Cronbach's Alpha lebih besar dari 0,6. Hal ini menunjukkan bahwa data penelitian dinyatakan reliabel.

Tabel 3. Hasil Uji Reabilitas

\begin{tabular}{lccc}
\hline \multicolumn{1}{c}{ Variabel } & $\begin{array}{c}\text { Cronbach's } \\
\text { Alpha }\end{array}$ & $\begin{array}{c}\text { Batas } \\
\text { Reliabilitas }\end{array}$ & Keterangan \\
& 0.706 & 0.6 & Reliabel \\
\hline Fasilitas Kerja (X1) & 0.732 & 0.6 & Reliabel \\
Motivasi Kerja (X3) & & & \\
\hline
\end{tabular}

Sumber: Hasil Penelitian 2020

\section{Uji Asumsi Klasik}

\section{Uji Normalitas}

Data menyebar disekitar garis diagonal dan mengikuti arah garis diagonal pada grafik histogram, hal ini menunjukkan bahwa pola distribusi normal. Jadi dapat disimpulkan bahwa berdasarkan grafik P-P plot, model regresi memenuhi asumsi normalitas.

\section{Uji Heteroskedastisitas}

Model regresi yang baik adalah tidak terjadi Heterokedastisitas. Untuk mendeteksi adanya Heterokedastisitas dapat dilakukan dengan menggunakan scatter plot. Dari hasil pengolahan diperoleh titik-titik dalam scatterplot menyebar. Hal ini berarti bahwa model regresi pada model ini tidak mengandung adanya masalah heteroskedastisitas, artinya semua variabel independen yang digunakan tidak mempengaruhi residualnya sehingga penelitian ini dapat diuji.

\section{Pengujian Hipotesis dengan Uji t}

Pengujian hipotesis dengan uji t, yaitu dengan memperhatikan nilai t hitung dari hasil regresi tersebut untuk mengetahui pengaruh variabel independen secara parsial terhadap variabel dependen dengan tingkat signifikansi dalam penelitian ini menggunakan alpha $5 \%$ atau 0,05. Nilai dari uji t hitung dapat dilihat dari p-value (pada kolom Sig.) pada masingmasing variabel independen, jika p-value lebih kecil dari level of significant yang ditentukan atau $\mathrm{t}$ hitung (pada kolom $\mathrm{t}$ ) lebih besar dari t tabel (dihitung dari two-tailed $\alpha=5 \% \mathrm{df}-\mathrm{k}, \mathrm{k}$ 
merupakan jumlah variabel independen), maka nilai variabel independen secara parsial berpengaruh signifikan terhadap variabel dependen (dalam arti Ha diterima dan Ho ditolak, dengan kata lain, terdapat pengaruh antara variabel independen terhadap variabel dependen).

Adapun metode dalam penentuan $t$ tabel menggunakan ketentuan tingkat signifikan 5 $\%$, dengan $\mathrm{df}=n-k-1$ (pada penelitian ini $\mathrm{df}=52-4-1=47$ ), sehingga didapat nilai $t$ tabel sebesar 2,011 disajikan dalam tabel sebagai berikut:

Tabel 4. Uji Parsial (Uji t) Persamaan 1

\section{Coefficients $^{\mathrm{a}}$}

\begin{tabular}{|c|c|c|c|c|c|c|}
\hline \multirow{2}{*}{\multicolumn{2}{|c|}{ Model }} & \multicolumn{2}{|c|}{ Unstandardized Coefficients } & \multirow{2}{*}{$\begin{array}{c}\text { Standardized } \\
\text { Coefficients } \\
\text { Beta }\end{array}$} & \multirow[b]{2}{*}{$\mathrm{T}$} & \multirow[b]{2}{*}{ Sig. } \\
\hline & & B & Std. Error & & & \\
\hline \multirow[t]{3}{*}{1} & (Constant) & 8.924 & 5.645 & & 1.581 & .120 \\
\hline & FasilitasKerja & .315 & .109 & .216 & 3.061 & .004 \\
\hline & MotivasiKerja & .281 & .105 & .300 & 2.668 & .010 \\
\hline
\end{tabular}

Sumber : Data diolah 2020

Dari hasil perhitungan uji secara parsial diperoleh nilai t hitung sebesar 3,145 dan nilai signifikansi sebesar 0,003. Karena nilai signifikansi lebih kecil dari 5\% maka hipotesis $(\mathrm{H} 1)$ diterima, yang berarti terdapat pengaruh signifikan positif antara variabel fasilitas kerja terhadap variabel motivasi kerja. Hal ini menunjukkan bahwa perusahaan yang mempunyai/memiliki fasilitas kerja yang lengkap mampu memotivasi pegawai dalam bekerja.

Pada pengujian hipotesis berdasarkan hasil perhitungan dapat dikatakan bahwa fasilitas kerja berpengaruh positif dan signifikan terhadap motivasi kerja di Kantor Pelayanan Pajak Pratama Lubuk Pakam. Dengan demikian secara simultan hasil penelitian ini telah sesuai dengan teori yang menyatakan bahwa fasilitas kerja signifikan terhadap motivasi kerja.

Pengaruh positif dan signifikan fasilitas kerja diterapkan di Kantor Pelayanan Pajak Pratama Lubuk Pakam, maka akan meningkatkan motivasi kerja. Artinya bahwa fasilitas kerja memiliki perananan yang penting dalam meningkatkan motivasi kerja.

\section{KESIMPULAN}

Penelitian ini melihat pengaruh fasilitas kerja terhadap motivasi kerja. Sehingga, penelitian ini memberikan kesimpulan bahwa secara statistik fasilitas kerja terbukti 
berpengaruh terhadap motivasi kerja pegawai di Kantor Pelayanan Pajak Pratama Lubuk Pakam. Nilai p-value (pada kolom Sig.) $0,003<0,05$.

\section{DAFTAR PUSTAKA}

George, R, Terry, Leslie W. Rue. 2003. Dasar-Dasar Manejemen. Jakarta: PT. Bumi Aksara.

Handoko T, Hani 2002. Manajemen Personalia dan Sumber Daya Manusia. Edisi Kedua. Yogyakarta: BPFE.

Siagian P. Sondang. 2003. Organisasi Kepemimpinan dan Perilaku Organisasi. Gunung Agung Jakarta

Sugiyono. 2007. Metode Penelitian Kuantitatif Kualitatif dan R\&D. Bandung: Alfabeta

Susilo, Sri Y, dkk. 2000. Bank dan Lembaga Keuangan Lain. Jakarta: Salemba Empat 